Martina Kurniarum

Wahyu Prihanta

Sri Wahyuni

Fatih Bisyria

Siti Zaenab

Ainur Rofieq

Feby Kurniawati

Iin Ratih

Wahyu Prihanta

Rr. Eko Susetyarini

Neni Lusiana

Abdulkadir Rahardjanto

Yusron Aminullah

Nurul Mahmudati

Candra Virgiawan

Iin Hindun

Sukarsono

Endrik Nurrohman

Veni Puspita Dewi

Nur Aisyah

Poncojari Wahyono

Dyah Ayu Ratnaningrum

Lise Chamisijatin

Nur Widodo

Septy Yustyan

Yuni Pantiwati
124

124

$124,148,196,208$

138

$138,148,177$

138,218

148

158

158,169

158

169

169,196

177

177

187

187,208

187

196

208

218

218

229

229

229,39

239

239 


\section{REVIEWER JPBI \\ VOLUME 1 NOMOR 2}

Naskah/artikel dalam penerbitan Volume 1 Nomor 2 ini telah direview oleh mitra bestari,
sebagai berikut:

Dr. Akhmad Sukri, M.Pd. (IKIP Mataram)

Dr. Marheny Lukitasari, M.Pd. (IKIP PGRI Madiun)

Dr. Yuni Pantiwati, MM., M.Pd. (Universitas Muhammadiyah Malang)

Dr. drh. Cicilia Novi Primiani, M.Pd. (IKIP PGRI Madiun)

Dr. Abdulkadir Rahardjanto, M.Si. (Universitas Muhammadiyah Malang)

Dr. Widodo, M.Pd. (UIN Sunan Kalijaga Yogyakarta)

Redaksi menyampaikan terima kasih dan penghargaan yang sebesar-besarnya atas kesedian dan keikhlasan para reviewer untuk mereview naskah-naskah pada

Volume 1 Nomor 2 ini. 


\section{Kepada Yth. Redaksi Jurnal Pendidikan Biologi Indonesia (JPBI)}

Kampus III Universitas Muhammadiyah Malang

Gedung Kuliah Bersama (GKB) 1 Lantai 5 Ruang Lorong Biologi

Jalan Raya Tlogomas No. 246 Telp: 0341- 464318 Ext.120 Fax: 0341- 460782

e-mail: biologi.umm@gmail.com

\section{FORMULIR BERLANGGANAN}

Nama (Instansi/Perorangan)

Alamat (Kantor/Rumah)

Kode Pos:

Telp/HP :

Harap dicatat sebagai pelanggan JPBI mulai nomor

sampai nomor

Harga langganan untuk 1 eksemplar terbitan adalah Rp. 70.000 atau Rp. 210.000 untuk satu volume (3 kali terbit). Uang langganan sebesar Rp.

$($.

akan/telah kami transfer ke rekening BNI 46 Cabang Pembantu Universitas Muhammadiyah Malang, Nomor Rekening: 0365672999, atas nama: EKO SUSETYARINI*).

Pelanggan,

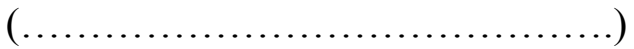

*) Scan bukti pembayaran/transfer harap diemailkan ke biologi.umm@gmail.com 

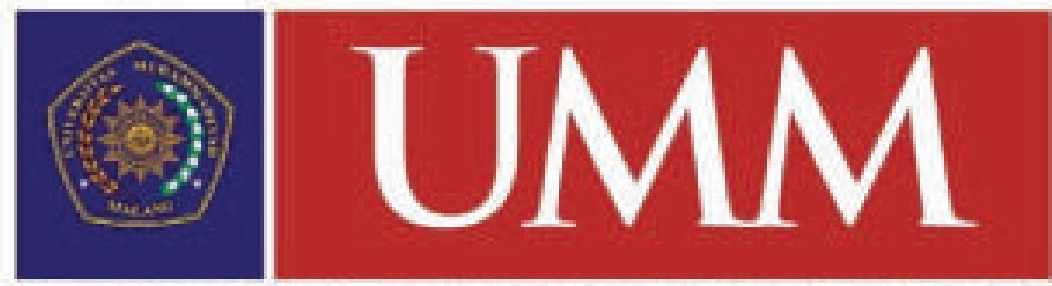

UNIVERSITAS MUHAMMADIYAH MALANG

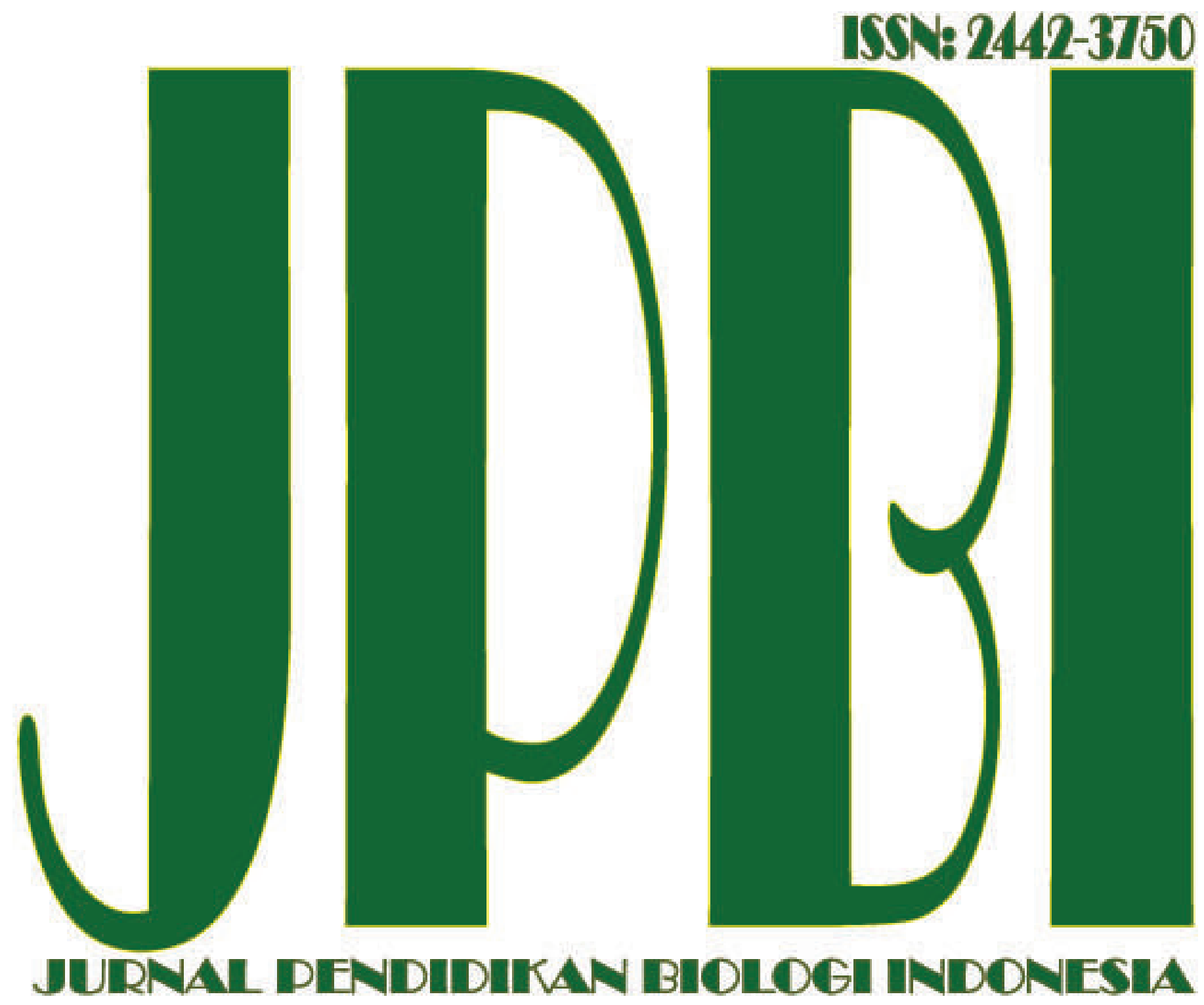

Redaksi:

Jl. Raya Tlogomas 246 Malang 65144

Kampus III UMM GKB I Lantai 5

Telp. (0341) 464318 psw 120; Fax. (0341) 460782

e-mail: biologi.umm@gmail.com/usya_bio@yahoo.com

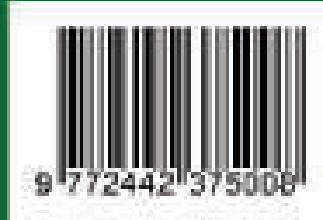

